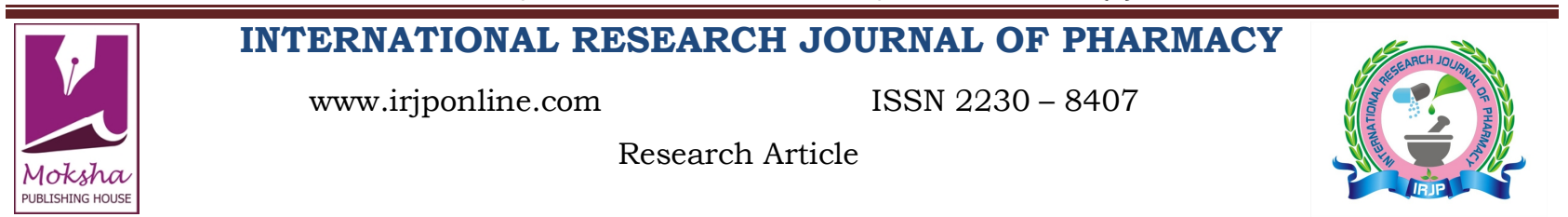

\section{ESSENTIAL OIL COMPOSITION AND ANTIOXIDANT ACTIVITY OF LAVANDULA ANGUSTIFOLIA FROM IRAQ}

Khitam Jawad Hamad ${ }^{1}$, Shahlah Jihad Ahmed Al-Shaheen ${ }^{1}$, Raad A Kaskoos ${ }^{1,2 *}$, Javed Ahamad ${ }^{2}$, Mohd. Jameel ${ }^{2}$, Showkat R. Mir ${ }^{2}$

${ }^{1}$ College of Pharmacy, Hawleer Medical University, Erbil, Iraq

${ }^{2}$ Phytochemistry Research Laboratory, Faculty of Pharmacy, Jamia Hamdard, New Delhi-110062, India

E-mail: raadkaskoos@gmail.com

Article Received on: 12/02/13 Revised on: 23/03/13 Approved for publication: 11/04/13

DOI: 10.7897/2230-8407.04421

IRJP is an official publication of Moksha Publishing House. Website: www.mokshaph.com

(C) All rights reserved.

\section{ABSTRACT}

The essential oil of Lavandula angustifolia Mill. growing spontaneously in Iraq was investigated by GC and GC/MS for the first time. The oil was extracted from the flowers by hydro-distillation. Thirty-four components amounting to $98.91 \%$ of the oil were identified. The major component being linalool (24.63 $\%)$. The other significant constituents were camphor $(13.58 \%)$, linalyl acetate $(8.89 \%),(Z)$ - $\beta$-ocimene $(7.59 \%)$, 1,8 -cineole $(7.14 \%)$, borneol $(6.41 \%),(E)$ $\beta$-ocimene (4.76\%), hotrienol (4.42\%), hexyl butyrate $(2.96 \%), \alpha$-bisabolol $(1.13 \%)$ and caryophyllene oxide (1.02 \%). The strong antioxidant activity of $L$. angustifolia oil was also examined using the stable 2,2-diphenyl-1-picrylhydrazyl-hydrate (DPPH) free radical scavenging method. Antioxidant activity of the oil was expressed as percentage of DPPH radical inhibition and $\mathrm{IC}_{50}$ values $(\mu \mathrm{g} / \mathrm{ml})$. Values of percentage inhibition ranged from 3.28 to $88.91 \%$ for 7.81 $\mu \mathrm{g} / \mathrm{ml}$ and $1000 \mu \mathrm{g} / \mathrm{ml}$, respectively with an $\mathrm{IC}_{50}$ value of $216 \mu \mathrm{g} / \mathrm{ml}$ for oil. The results suggest the use of lavender oil as effective natural antioxidants.

Keywords: Lavandula angustifolia, volatile oil, GC-MS, linalool, DPPH.

\section{INTRODUCTION}

Lavandula angustifolia (syn. L. officinalis Chaix) is an important perennial shrub of family Labiatae (Lamiaceae). The lavender is widely distributed in the Mediterranean region and cultivated in France, Spain and Italy. Mainly two species, L. angustifolia and L. stoechas and their subspecies and hybrid forms grow wildly or are cultivated ${ }^{1}$. $L$. angustifolia is reported to have neuroprotective ${ }^{2}$, antibacterial $^{3}$, antimutagenic ${ }^{4}$ and antifungal ${ }^{5}$ activities. Lavender oil is known for its excellent fragrance and is comprehensively used in the perfumery, flavour and cosmetic industries as well as medicinal purpose ${ }^{6}$. Lavender oil is also reported to be an effective antifungal agent against Aspergillus nidulans and Trichophyton mentagrophytes ${ }^{7}$. The essential oil compositions of lavender grown in different countries have been investigated. Oil from India has become more significant competitor with historical sources of lavender oil due to the favorable climatic situations for commercial cultivation in the hilly tracks of Northern India ${ }^{8,9}$. The aim of this study was to evaluate the chemical composition of essential oil of L. angustifolia used for the production of lavender oil in Iraq by GC and GC-MS; and its antioxidant potential for the application of the essential oil in food preservation and in medicine.

\section{MATERIAL AND METHODS Plant Material}

Flowers of L. angustifolia were collected from the Shaqllawa, Iraq in the month of March-April, 2012. The sample was identified and a voucher specimen of the plant was submitted to the Phytochemistry Research Laboratory, Jamia Hamdard, New Delhi.

\section{Chemicals}

BHA (3-tert-butyl-4-hydroxyanisole), BHT (butylated hydroxy toulene), Vitamin C and DPPH (2,2-dyphenyl-1picrylhydrazyl) were obtained from SIGMA CHEMICALS
CO., ST. LOUIS, MO, USA. All other solvents and chemicals were of analytical grade.

\section{Isolation of volatile oil}

Samples (200 gm) were hydro-distilled for six hours with Clevenger apparatus. The volatile oil was collected in the graduated tube. The collected volatile oil was dried over anhydrous sodium sulphate and stored at $4{ }^{0} \mathrm{C}$ in the dark. The yield of volatile oil obtained was $1.5 \% \mathrm{v} / \mathrm{w}$.

\section{GC-FID Analysis}

GC was carried out on Shimadzu 2010 gas chromatograph (Japan) equipped with a flame ionization detector (FID) and AB-Innowax 7031428 WCOT fused capillary column $(60 \mathrm{~m}$ X $0.25 \mathrm{~mm} \times 0.25 \mu \mathrm{m})$. The injector and detector temperatures were maintained at 250 and $270{ }^{\circ} \mathrm{C}$, respectively. The carrier gas used was nitrogen at a flow rate of $1.21 \mathrm{ml} / \mathrm{min}$ with column pressure of $101.1 \mathrm{kPa}$. The sample $(0.2 \mu \mathrm{l})$ was injected into the column with a split ratio of 80:1. Component separation was achieved following a linear temperature programmed from $60-230^{\circ} \mathrm{C}$ at a rate of 3 ${ }^{\circ} \mathrm{C} / \mathrm{min}$ and then held at $230{ }^{\circ} \mathrm{C}$ for $9 \mathrm{~min}$, with a total run time of $50 \mathrm{~min}$. Percentage of the constituents were calculated by electronic integration of FID peak areas.

\section{GC-MS Analysis}

The analysis of the volatile constituents were run on a Shimadzu QP-2010 GC-MS system equipped with ABInnowax 7031428 WCOT column $(60 \mathrm{~m} \times 0.25 \mathrm{~mm} \times 0.25$ $\mu \mathrm{m})$ directly coupled to the MS. The carrier gas was helium with a flow rate of $1.21 \mathrm{ml} / \mathrm{min}$ with column pressure of 81.7 $\mathrm{kPa}$. Oven temperature was programmed as $50{ }^{\circ} \mathrm{C}$ for $1 \mathrm{~min}$ and subsequently held isothermal for $2 \mathrm{~min}$. The injector and detector temperatures were $250{ }^{\circ} \mathrm{C}$ and $280{ }^{\circ} \mathrm{C}$, respectively. The sample $(1 \mu \mathrm{l})$ was injected into column with a split ratio of 1:100. Recording was performed at $70 \mathrm{eV}$, scan time $1.5 \mathrm{~s}$; mass range 40-750 amu. Software adopted to handle mass spectra and chromatograph was Chem station. 
Table 1: Essential oil constituents of Lavandula angustifolia Mill.

\begin{tabular}{|c|c|c|c|c|c|}
\hline S. No. & Compound & RI & $\mathbf{R}_{t}$ & $\%$ Area & EP $5^{14}, \%$ \\
\hline 1. & $n$-Hexanol & 878 & 2.365 & 0.45 & \\
\hline 2. & 3-Nonyne & 896 & 2.644 & 0.11 & \\
\hline 3. & 2,7-Dimethyl oxepine & 930 & 3.161 & 0.52 & \\
\hline 4. & Camphene & 950 & 3.450 & 0.36 & \\
\hline 5. & 3-Octanone & 983 & 3.954 & 0.37 & $0-2$ \\
\hline 6. & Myrcene & 989 & 4.042 & 0.74 & \\
\hline 7. & cis-Linalool oxide & 993 & 4.105 & 0.95 & \\
\hline 8. & Hexyl acetate & 1009 & 4.437 & 0.96 & \\
\hline 9. & 1,8-Cineole & 1032 & 4.988 & 7.14 & $<2.5$ \\
\hline 10. & $\gamma$-Valerolactone & 1040 & 5.166 & 0.72 & \\
\hline 11. & (Z) $\beta$-Ocimene & 1043 & 5.253 & 7.59 & $2-6$ \\
\hline 12. & (E) $\beta$-Ocimene & 1074 & 5.997 & 4.76 & $4-10$ \\
\hline 13. & Linalool & 1107 & 6.828 & 24.63 & $20-45$ \\
\hline 14. & Hotrienol & 1110 & 6.917 & 4.42 & \\
\hline 15. & 3-Octyl acetate & 1121 & 7.297 & 0.28 & \\
\hline 16. & Camphor & 1149 & 8.188 & 13.58 & $<1.2$ \\
\hline 17. & Nerol oxide & 1153 & 8.322 & 0.74 & \\
\hline 18. & Borneol & 1170 & 8.856 & 6.41 & \\
\hline 19. & trans-Linalool oxide & 1175 & 9.016 & 0.57 & \\
\hline 20. & Hexyl butyrate & 1192 & 9.542 & 2.96 & \\
\hline 21. & 2,6-Dimethyl-3,5,7-octatriene-2-ol & 1202 & 9.881 & 5.39 & \\
\hline 22. & Isobornyl formate & 1228 & 10.835 & 0.59 & \\
\hline 23. & Hexyl-2-methyl butyrate & 1234 & 11.084 & 0.61 & \\
\hline 24. & 2-Cyclohexene-1-one-2-methyl-5-(1-methyl ethane) & 1244 & 11.428 & 0.11 & \\
\hline 25. & Linalyl acetate & 1256 & 11.888 & 8.89 & $25-46$ \\
\hline 26. & Lavandulyl acetate & 1290 & 13.129 & 0.27 & $>0.2$ \\
\hline 27. & Hexyl tiglate & 1329 & 14.638 & 0.69 & \\
\hline 28. & 8-Acetoxy linalool & 1376 & 16.495 & 0.18 & \\
\hline 29. & Geranyl acetate & 1383 & 16.748 & 0.32 & \\
\hline 30. & trans-Verbenol acetate & 1414 & 17.970 & 0.58 & \\
\hline 31. & Lavandulyl isovalerate & 1507 & 21.589 & 0.13 & \\
\hline 32. & Caryophyllene oxide & 1580 & 24.341 & 1.02 & \\
\hline 33. & $\alpha$-Bisabolol oxide B & 1651 & 26.977 & 0.13 & \\
\hline 34. & $\alpha$-Bisabolol & 1682 & 28.098 & 1.13 & \\
\hline \multicolumn{4}{|c|}{ Total identified, $\%$} & 98.91 & \\
\hline
\end{tabular}

RI: Retention Index, $\mathbf{R}_{\mathbf{t}}$ : Retention time on column, *compounds less than $0.1 \%$ was considered minor. ${ }^{14}$ European Pharmacopoeia 5.0

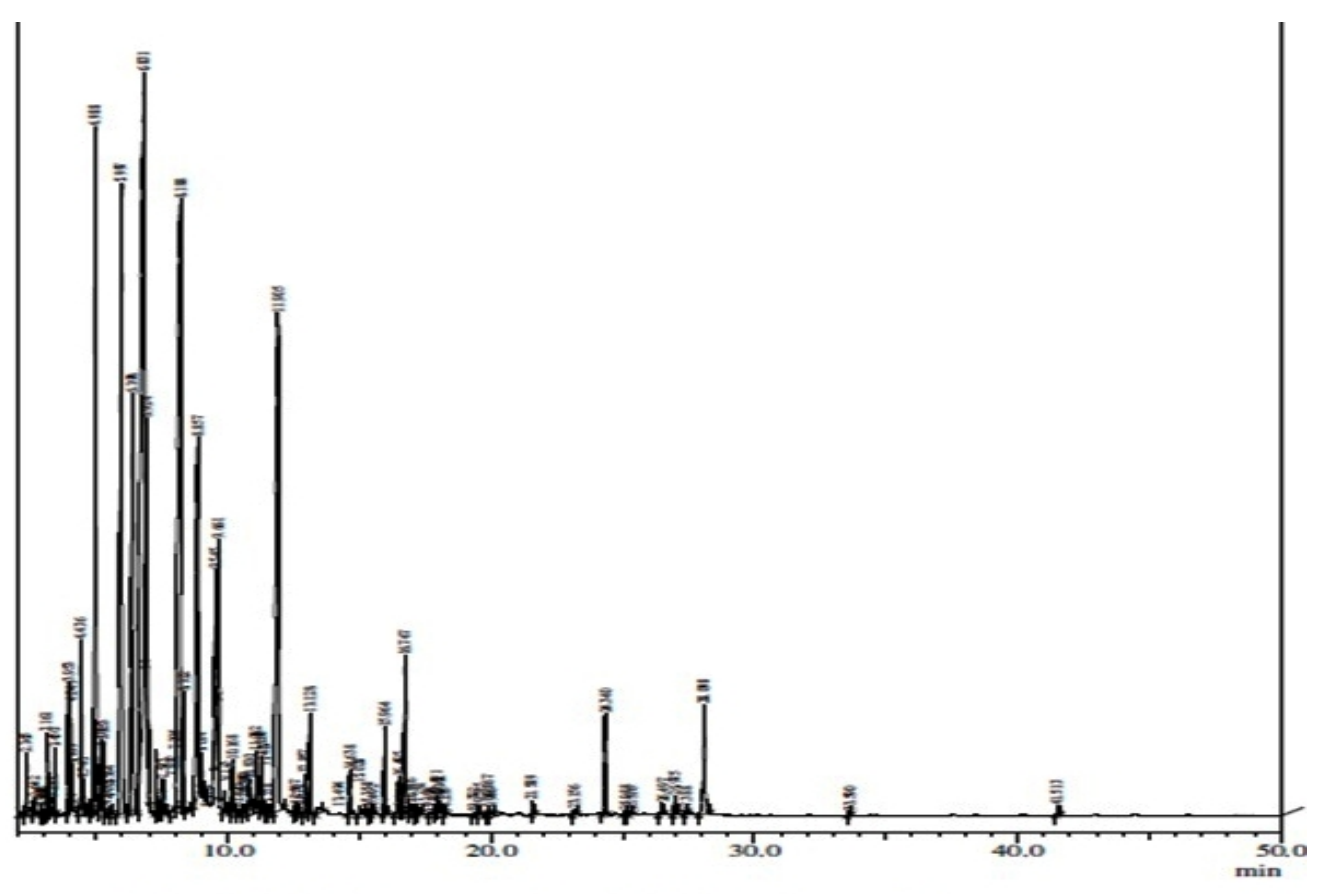

Figure 1. GC-MS chromatogram of essential oil of Lavandula angustifolia 


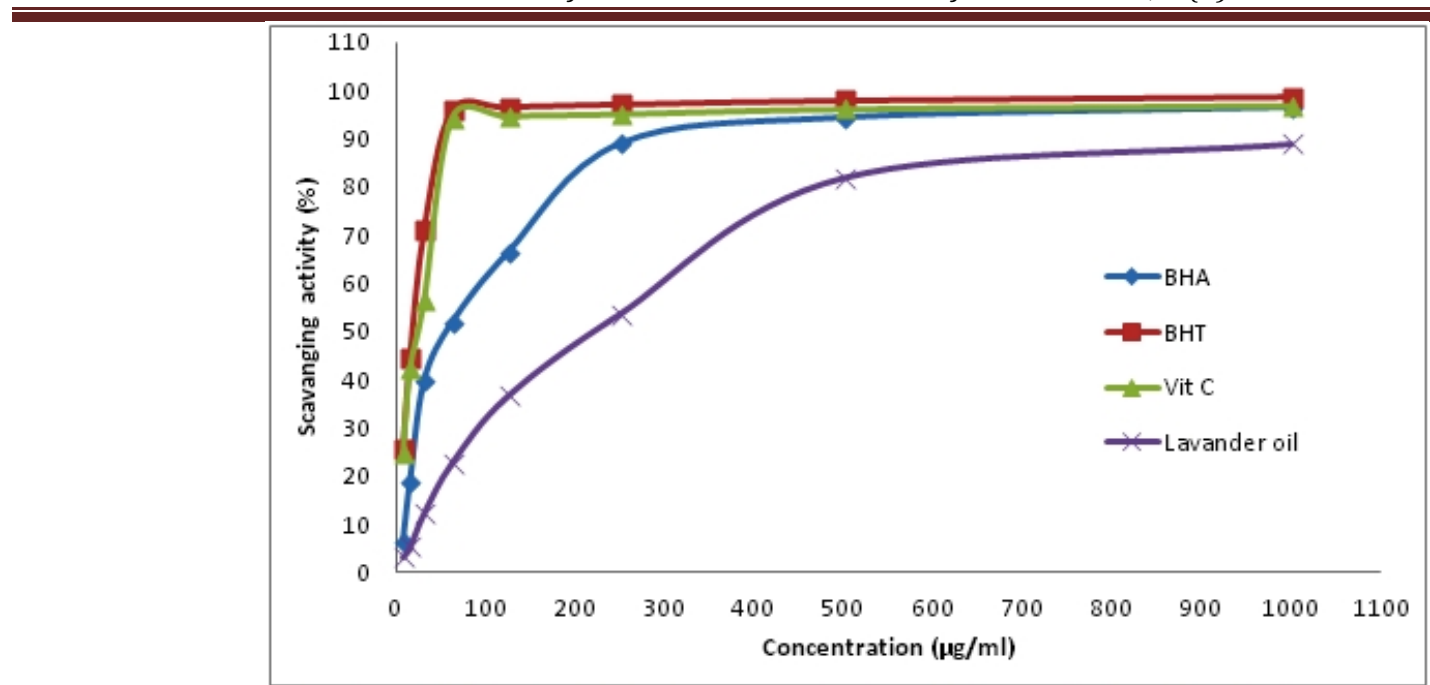

Figure 2. Antioxid ant (DPPH scavenging) activity of st and ard BHA, BHT, Vitamin C and

volatile oil of $L$. angustifolia

\section{Evaluation of antioxidant activity}

The ability of a substance to scavenge DPPH free radicals was assessed by the standard method ${ }^{10}$, adopted with suitable modifications ${ }^{11}$. The stock solution of oil was prepared in methanol to achieve the concentration of $1 \mathrm{mg} / \mathrm{ml}$. Dilutions $1000,500,250,125,62.5,31.25,15.62$ and $7.81 \mu \mathrm{g} / \mathrm{ml}$ were prepared by serial dilution method. Diluted solutions $(1 \mathrm{ml}$ each) were mixed with $1 \mathrm{ml}$ of methanolic solution of DPPH $(1 \mathrm{mg} / \mathrm{ml})$. After $30 \mathrm{~min}$ incubation in darkness at room temperature $\left(23^{\circ} \mathrm{C}\right)$, the absorbance was recorded at $517 \mathrm{~nm}$. Control sample contained all the reagents except the oil. Percentage inhibition was calculated using equation given below:

$$
\% \text { Inhibition }=\frac{\Lambda \operatorname{co}-\Lambda t}{A \operatorname{co}} \times 100
$$

where, $A_{C O}$ is absorbance of the control and $A_{t}$ is absorbance of the samples.

$\left[\mathrm{IC}_{50}\right.$ values were estimated from the $\%$ inhibition versus concentration plot using a non-linear regression algorithm].

\section{Identification of volatile oils}

The individual peaks/constituents were identified by GC by comparison of their retention indices (R.I.) either with retention indices of linear compounds available or published literature $^{9,12}$ reports. Further identification was made by comparison of fragmentation pattern of mass spectra obtained by GC-MS analysis with those stored in the spectrometer database of NBS 54 K.L, WILEY8 libraries. Retention indices of the components were determined relative to the retention time of a series of $n$-alkanes relative to $\mathrm{C}_{9}-\mathrm{C}_{20}$ on HPS and HP-20M columns. The relative amount of the individual components was calculated from the peak area without applying an FID response factor correction.

\section{RESULTS AND DISCUSSION}

Lavender oil is used traditionally for the treatment of various complaints from ancient timefor its excellent aroma worldwide. It is extensively used in the perfumery, flavor, cosmetic industries and as sedative, carminative, antidepressive, antiinflammatory and antibacterial potential. The essential oil composition of the fresh flowers of $L$. angustifolia was determined by GC and GC-MS analysis. Chromatogram is shown in Fig. 1 and compounds identified in the essential oil are given in Table 1. A total of 34 compounds were identified that constitute $98.91 \%$ of the total volatiles. The major constituents $(>1.0 \%)$ of the oil were linalool (24.63\%), camphor (13.58 \%), linalyl acetate (8.89\%), 1,8-cineole (7.14\%), (Z)- $\beta$-ocimene (7.59\%), borneol (6.41\%), 2,6-dimethyl-3,5,7-octatriene-2-ol (5.39 $\%$ ), (E)- $\beta$-ocimene (4.76 \%), hotrienol (4.42\%), hexyl butyrate $(2.96 \%), \alpha$-bisabolol $(1.13 \%)$ and caryophyllene oxide (1.02\%). Linalool and linalool-rich essential oils are known to exhibit various biological activities such as antimicrobial, antiinflammatory, anticancer and antioxidant properties. Linalool is also a key compound for the industrial production of a variety of fragrance chemicals such as geraniol, nerol, citral and its derivatives, as well as a lead compound in the synthesis of vitamins $\mathrm{A}$ and $\mathrm{E}^{13}$.

On comparison of the present results with those reported from samples of other countries, it is quite evident that the concentrations of 1,8-cineole, camphor, (Z)- $\beta$-ocimene, $(E)$ $\beta$-ocimene, hotrienol and borneol were slightly higher, whereas the concentration of nerol, caryophyllene, elemol, cadinene, terpineol, thymol acetate, lavandulol, limonene and $\alpha$-pinene were marked less in this sample ${ }^{9,12}$. The concentrations of linalool and linalyl acetate are with the range of European Pharmacopoeia ${ }^{14}$. The observed differences in the constituents of lavender essential oil in the present study may be due to different environmental and genetic factors, different chemotypes and the nutritional status of the plants.

The antioxidant activity of essential oil of L. angustifolia was determined using a methanol solution of DPPH reagent. The antioxidant activity of essential oil of $L$. angustifolia was expressed in terms of percentage of inhibition (\%). Parallel to examination of the antioxidant activity of the oil, the values for three standard compounds were obtained and compared with the antioxidant activity of essential oil of lavender. The standard substances were BHA, BHT and Vitamin C. a plot of \% inhibition verses concentration given in Fig 3 was used to calculate $\mathrm{IC}_{50}$ values. The examination of antioxidant activity of essential oil of $L$. angustifolia showed concentration dependant response and varied from 3.28 to $88.91 \%$ for 7.81 to $1000 \mu \mathrm{g} / \mathrm{ml}$, respectively. The $\mathrm{IC}_{50}$ values of standard BHT, Vitamin C and BHA and essential oil of $L$. angustifolia was found to be $16 \mu \mathrm{g} / \mathrm{ml}, 24 \mu \mathrm{g} / \mathrm{ml}, 52 \mu \mathrm{g} / \mathrm{ml}$ 
and $216 \mu \mathrm{g} / \mathrm{ml}$, respectively. The high content of linalool was postulated to contribute to the antioxidant activity of the oil. The L. angustifolia can thus be regarded as promising candidate from natural plant sources of antioxidants with high value.

\section{REFERENCES}

1. Mill RR Flora of Turkey and the East Aegean Islands (Davis, PH). 7th ed. University Press Edinburgh, 1982. p. 77-79.

2. Wang D, Yuan X, Liu T, Liu L, Hu Y, Wang Z, Zheng Q. Neuroprotective activity of lavender oil on transient focal cerebral ischemia in mice. Molecules, 2012; 17(8): 9803-9817. http:// dx.doi.org/10.3390/molecules17089803 PMid:22895026

3. Lodhia MH, Bhatt KR, Thaker VS. Antibacterial activity of essential oils from Palmarosa, evening primrose, lavender and tuberose. Indian J Pharm Sci., 2009; 71(2): 134-136. http://dx.doi.org/10.4103/0250474X.54278 PMid:20336210 PMCid:2839398

4. Evandri MG, Battinelli L, Daniele C, Mastrangelo S, Bolle P, Mazzanti G. The antimutagenic activity of Lavandula angustifolia (lavender) essential oil in the bacterial reverse mutation assay. Food Chem Toxicol., 2005; 43(9): 1381-1387. http://dx.doi.org/10.1016/ j.fct.2005.03.013 PMid:15907354

5. Dauria FD, Tecca M, Strippoli V, Salvatore G, Battinelli L, Mazzanti G. Antifungal activity of Lavandula angustifolia essential oil against Candida albicans yeast and mycelial form. Med Mycol., 2005; 43(5): 391-396. http://dx.doi.org/10.1080/13693780400004810

6. Cavanagh HM, Wilkinson JM Biological activities of lavender essential oil. Phytotherap Res., 2002; 16(4): 301-308. http://dx.doi.org/10.1002/ ptr.1103 PMid:12112282

7. Moon T, Chan YF, Wilkinson JM, Cavanagh HMA In Proceeding of AICA National Conference, Adelaide, Australia, 46 (Abstract) (2004).
8. Adams R, Yanke T. Variation in composition and enantiomeric analyses of commercial vs. new Kashmir clary sage oils. Perf. Flav., 2007; 32(9): 36-39.

9. Verma RS, Rahman LU, Chanotiya CS, Verma RK, Chauhan A, Yadav A, Singh A, Yadav AK. Essential oil composition of Lavandula angustifolia Mill. cultivated in the mid hills of Uttarakhand, J. Serb. Chem. Soc., 2010; 75(3): 343-348. http://dx.doi.org/10.2298/J SC090616015V

10. Tekao T, Watanabe N, Yagi I, Sakata K. A simple screening method for antioxidant and isolation of several antioxidants produced by marine bacteria from fish and shellfish. Biosci. Biotech. Biochem., 1994; 58: 1780-1783. http://dx.doi.org/10.1271/bbb.58.1780

11. Roby MHH, Sarhan MA, Selim KAH, Khalel KI. Evaluation of antioxidant activity, total phenols and phenolic compounds in thyme (Thymus vulgaris L.), sage (Salvia officinalis L.), and marjoram (Origanum majorana L.) extracts. Ind. Crops. Prod., 2013; 43: 827-831. http://dx.doi.org/10.1016/j.indcrop.2012.08.029

12. Shelliea R, Mondellob L, Marriotta P, Dugob G. Characterisation of lavender essential oils by using gas chromatography-mass spectrometry with correlation of linear retention indices and comparison with comprehensive two-dimensional gas chromatography. J. Chromatograph A, 2000; 1: 1-5.

13. Kamatou GPP, Viljoen AM. Linalool-A review of a biologically active compound of commercial importance. Nat. Prod. Comm., 2008; 3: 1183-1192.

14. European Pharmacopoeia, 5th Ed. 2005; p. 1894.

Cite this article as:

Khitam Jawad Hamad, Shahlah Jihad Ahmed Al-Shaheen, Raad A Kaskoos, Javed Ahamad, Mohd. Jameel, Showkat R. Mir. Essential oil composition and antioxidant activity of Lavandula angustifolia from Iraq. Int. Res. J. Pharm. 2013; 4(4):117-120 